\begin{tabular}{ll}
\hline 随 \\
\hline
\end{tabular}

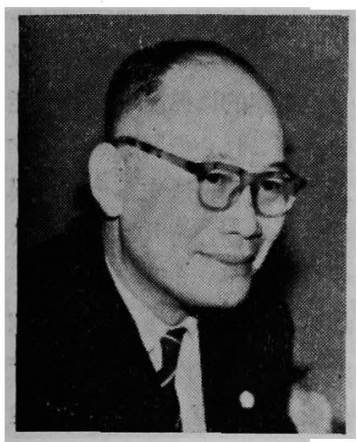

\title{
鉄 鋼業の現状に思う
}

佐橋滋*

わが国経済の不況は，景気振興策の渗透により，最近その局面に若干の好転の兆 がみられつつあるが，産業界全般が本格的立ち直りをみせるまでには，まだかなり の時日を要するものと思わ机る. 今回の不況は, 過去十年近くに亘る経済の高度成 長の後をうけ，その反動によるものであり，さらに開放経済体制への移行が機を一 にしたため, 従来の景気後退期にはみられなかつた多くの課題を提起する結果とな つているが，こ机が解決に当つては単に政府のみならず民間産業界に打いて子積極 的な施策を展開する必要があることはいうまでもない，現在，鉄鋼業が当面している幾つかの課題もその例外ではな く，鉄鋼業界の安定とその健全な発展のため，官民一体となつて，英知の全てを傾注すべき時で西ると思われるが， 以下これらの点に関し日頃私が抱いている所懐の一端を述べてみたい

わが国の鉄鋼業は粗鋼生産高において，すでに米りに次ぐ世界第三位の座をしめ，また目覚ましい輸出の発展によ つても明らかなごとく, コスト，品質両面における国際競争力は申分のない水準に達している. 戦後の荒廃から立ち 直つた日本鉄鋼業が，かかる輝しい発展を遂げ得た理由としては，もち万え多くの見方がなされるこころであるが， 秮法何をさておいても，鉄鋼業の経営陣，技術陣に豊富な人材を得たこと，さらにその人達の積極果敢な進取性を強 く指摘したい、すなわち，戦後いち早く，平和経済への移行が必ずや鉄鋼消費の拡大と多様化をもたらすであろうと 判断した経営者の卓越した洞察力や，またかかる变革に対応するため, 新しい臨海製鉄所の建設や,ストリップ・ミ ルの導入, 純酸素転炉の採用など積極的な技術革新に踏み切つた技術陣の英知が，今日の隆盛の基盤を築き上げたと いつても決して過言でなからう．特にわが国の鉄銅技術者は基幹産業の担い手としての責務に燃えて日頃の研さんに も厚く, このため新技術採用に当つては, その評価の適確なことおよびその消化の迅速な点で世界的にも抜きえでて 高い水準にあるものと思う。

このように，優れた技術陣に恵まれ，隆々と発展してきたかが国鉄鋼業も，今や大きな曲り角にさしかかつたとみ られる。すなわち, 内にあっては不況の早期克服が急がれるとともに, 外に対しては輸出の秩序ある拡大が強く要請 されて拉り，こ礼らを通じて鉄銅業の安定成長路線をいかに確立するか，その具体的方策について真剣な検討を重衫 るべき段階にあるといえよう。過去 10 年間におけるわが国鉄鋼生産の年間平均伸び率法实: $18 \cdot 7 \%$ に達するが， 今後の鉄鋼需要の伸びについては，その見通しが非常に難かしい時期にある.わが国における1 人当り粗鋼見掛消費 量はすでに $300 \mathrm{~kg}$ を超え, 西欧の水準に近接しつつあるものの, 1 人当り国民所得は去扮西欧諸国の 5 割の水準に とどまつており，したがつて従来は所得水準に比して，はるかに急速な鉄鋼消費の伸びがあつたと考光られる。しか し今後の鉄鋼需要については，このような伸びを期待することは無理であり，所得水準の上昇に並行する安定成長う インに沿つた緩やかな拡大を示すものと考えるのが妥当ではなかららか。需要が急速に拡大しつつある時期において は，各社の旺盛な設備投資意欲が技術革新の推進力ともなり，鉄鋼需給の面にさしたる問題を生じないまま，鉄鋼業 の高度成長を可能とした。しかし前述のごとく、今後の鉄鋼需要が安定成長パターン沉移行するとすれば現在もなお 旺盛な各社の設備投資計画はそれがそのままの姿で実現しうる情勢にはないと考えざるをえない、

他方において，現在世界の有力製鉄国において合理化の波が新たな高まりをみせつつある点に，注目を要しょう。 すなわち, 米国鉄鋼業においては本年の設備投資額は18億ドル, さらに明年は23億ドル超点, 未曾有の高水準に達 するむのと見込まれ，既存製鉄所の大更新，中西部における新製鉄所の建設，純酸素転炉や連続鍀造設備など新技術

\footnotetext{
* 通商産業省事務次官
} 
の積極的な採用など，かつてみられなかつた大規模な合理化が始まりつつある.またり連においても巨大な一貫工場 の新設が各所に計画され，米国におけると同様連続鋳造技術を中心とした新技術の活用が積極的に推進されつつある といわれる.このような各国鉄鋼業の動向は，一方においてわが国鉄鋼業の目覚ましい発展に刺激された結果とみら れるが，一製鉄所の操業単位が年間 1 千万 $\mathrm{t}$ を超え, 製品の重量単位も従来の 2 倍, 3 倍と大型化するといわれるご とく, 鉄鋼生産技術がはるかに大きなスケールに移行する傾向を示すものとも考えられる.したがつて設備合理化に ついて，世界の最先端を歩えできた日本鉄鋼業が，今後ともその地位を保つて行くには，なお技術革新に対応して設 備近代化を推進して行かね壮なら奴ことはいうまでもない，しかしながらそれにともなつて必然的に派生する設備能 力增大の問題については, この際特に慎重な配虑を払う必要があ万う. 欧州諸国においては, これらの問題を解決す る一方策としていわゆる国境をこえた共同投資という企業協調の動きが表われているが，経済発展の歴史と土壤を異 にするわが国沈いて，それをそのまま移植することの当否は，種々議論の岐れるところであろう．それはとるかく として，日本鉄鋼業の英知を結集し，ここで拔本的な解決策を生みだしてほしいところである。

日本鉄鋼業を取り巻く以上のごとき情勢を考虑すると，業界の発展に果す技術の役割は，今後一層高まるものと認 められる.すなわち, 技術革新を一層推進することによりコストの引下げと，国際競争力の強化をはかるのみならず 製品の高度化と質的向上により新規需要の開発を推進することが，今後業界の安定をもたらすための，不可欠の方途 であると考えられ，このため技術開発の緊要性は急速汇高まりつつある。不幸にしてわが国鉄鋼業は欧米諸国に比し て比較的その歴史が浅く，また戦時中に技術開発の努力が中断したなどの事情もあつて，わが国独自の技術を生みだ す力は，諸外国に比べて，幾分劣るところがあることも否めない事実であろう．このため戦後採用された新技術の大 部分は外国からの導入に依存するところとなつているが，これは発展の一時期としては当然の措置でもあり，これを もつてわが国鉄鋼技術者の資質を云々することは当らず，むしろ今後の飛躍に期待すべきものと考える．最近，わが 国独自の基盤の下で生まれた新しい技術が，海外諸国で高く評価され，その一部が欧米諸国にも輸出されていること は，この点からみても非常に頼もしいことであり，今後かかる方向に沿つた技術開発が一層促進されるべきものと思 う。また技術開発の体制については，現在各国とも開発プロジェクトが大規模化しつつある点に鑑み，広く国の内外 を含めた共同研究体制の確立により，研究活動の効率化をはかるべきものと考えられるが，その具体化は他方におい て業界協調の基盤䤑成に貢献与るところきわめて大きいと思われる.日本鉄鋼協会の最近の活動はかかる共同研究体 制の確立を目指し，すでに鉄鋼技術共同研究会をはじめ数々の事業が大規模にかつ精力的に展開され着々とその成果 が収められつつあるが，その先駆的役割は高く評価されるところである. 今後さらに産学共同体制の強化と業界協調 の確立を実現し，50年に亘る輝しい伝統を一層栄えあるものとし，新たな飛翟を遂げられるよう心から期待するもの である. 